\title{
Hogyan utazzunk a COVID járvány után? How can we travel after the COVID-19 pandemic?
}

\author{
Szerző: Felkai Péter ${ }^{1}$
}

\begin{abstract}
A COVID-19 járvány lecsengésével egyidejüleg a nemzetközi utazások is elkezdődnek majd. Azonban sem az utazás megszokott formái, sem az utazók utazással kapcsolatos attitüdjei nem lesznek ugyanazok, mint járvány előtt. Mivel mindenkinek a biztonságos utazás az érdeke, a járványos megbetegedések prevenciója elsődleges fontosságúvá válik. Ennek egyetlen módja az utazás előtti egészségügyi felkészítés. Az orvosi tanácsadással az utazással összefüggő betegségek nagy része megelőzhető. A tanácsadás a COVID járvány után ki kell, hogy terjedjen a vírusfertőzés megelőzésének módjaira, illetve a biztonsági rendszabályok ismertetésére is. Azonban a biztonságos utazás és utaztatás biztosítása nem csak orvosi feladat. A megelőző intézkedések az utazási iparág minden szereplőjének ismeretanyagát kell, hogy képezzék. Ezeket az új ismereteket foglalja össze a tanulmány.
\end{abstract}

International travel will resume in parallel to the decline of COVID-19 pandemic. However, neither travel practices nor travellers' attitudes will be the same as before. Travel safety is in the common interest of both travellers and of the actors in the travel business, and so the prevention of travelrelated illnesses and communicable diseases is of fundamental importance. The only way to manage this is appropriate pre-travel advice for travellers. Withh the help of pre-travel counselling, the majority of medical problems could be prevented. The post-covid way of pre-travel advice must include the prevention of COVID infection, as well as other safety measures. At the same time, the task of ensuring safe travel is not exclusively medical business. All safety and preventive measures must be known and must be implemented by all participants in the travel business. This article offers a brief summary of these issues.

Kulcsszavak: COVID-19, utazási tanácsadás, védőoltások, légi utazás, utazási biztosítás. Keywords: COVID-19, pretravel counseling, vaccination, air travel, travel insurance.

\section{Bevezetés}

A rémálom egyszer véget fog érni: a határok újra kinyílnak, az utazási irodák újra kínálni fogják külföldi útjaikat, a hotelek szobáit ismét le lehet foglalni, megtelnek az éttermek asztalai és a nevezetességek újra látogathatóak lesznek. Az idegenforgalomból élő emberek és vállalkozások számára visszatér a remény, hogy lesz megélhetésük. Az idegenforgalmi üzletág ugyanis hatalmas veszteséget könyvelt el: a 2020. évben az előzó évi teljes bevétel 40\%-át érték csak el, és mivel a krízis 2020 decemberéig folytatódott, a becsült visszaesés 80\%ra nótt (OECD 2020a). Hazánk hetedik az OECD országok között, amelyek a turizmusból átlag feletti GDP növekedést élveztek. Mivel a turizmusból befolyó teljes GDP 45\%-a hazánkban a belföldi turizmus árbevételéből származik (Németországban $80 \%$ !), mely értékkel az OECD országok közül az utolsó 7 ország között vagyunk, világos, hogy az utazási megszorítások (házi karantén) a hazai turizmust is sújtják (OECD 2020b). Minden szektornak érdeke tehát, hogy a nemzetközi utazás és a turizmus minél előbb helyreálljon.

Az utazás azonban ezután már nem lesz olyan, mint a járvány előtt. Nyilvánvaló, hogy a COVID járványt a nemzetközi utazás tette világjárvánnyá. Elfeledtük a nagy tanulságot: a járványokat mindenkor az embertömegek mozgása terjesztette,

\footnotetext{
${ }^{1}$ címzetes egyetemi docens, Debreceni Egyetem Orvostudományi Kar, peter.felkai@soshungary.hu
} 
legyenek azok katonák, kereskedôk, zarándokok vagy a tömegturizmusban résztvevők. A különbség csak annyi, hogy amíg az 1345. évi nagy pestisjárvány, mely kiirtotta Európa lakosságának felét, 8 év alatt jutott el Ázsiából Európa legnyugatibb csücskébe, addig a korunkbeli járványok - illetve a kórokozókat hordozó emberek és tárgyak - alig 24 óra alatt körbeutazzák a Földet. A modern közlekedési eszközök igen rövid idő alatt juttatnak el nagy embertömegeket nagy távolságokra, és ez okozza a járványok egyre gyakoribbá válását. $\mathrm{Az}$ első ilyen szuperszónikus sebességgel terjedő járvány 1990-ben az úgynevezett kifutópálya malária volt, amikor trópusi országokban repülógépbe zárt szúnyogok kerültek Londonba, terjesztve a betegséget. Ezután egyre gyakrabban követték egymást a világon elterjedô fertőző betegségek: 1996-ban az AIDS, 2002-ben a SARS, 2003-ban a madárinfluenza, 2009-ben a sertésinfluenza (H1N1), 2015ben a MERS, 2016-ban a Zika vírus és 2019-ben a COVID járvány. Tehát egy következő világjárvány kitörése már évek óta várható volt (FELKAI 2018). Mindazonáltal az említett járványok kedvezótlen gazdasági hatása töredéke volt a COVID járványnak. A turizmus elérte végső határait: a 6000 fốt szállító luxushajók, a 850 fót szállító repülógépek olyan turistainváziót jelentettek a népszerú idegenforgalmi célpontokban, hogy Velencére, Prágára vagy Barcelonára nyugodtan kitehették volna a megtelt táblát. A pontot az i-re, úgy túnik, a COVID járvány tette fel.

Egy biztos: az eddigi utazási és utaztatási szokások tovább nem tarthatóak. Ugyanakkor, kár lenne lemondani az idegen országok nyújtotta kulturális kincsek megtekintéséről, a tengerparti nyaralások kikapcsolódási lehetőségeirôl vagy a szabadidősportok aktív pihenésérooll. Ezért újra kell gondolnunk az utazás során az egészségünket védő és az utazással együtt járó betegségek megelőzésére szolgáló módszereket és taktikákat.

\section{Módszertan}

Jelen kutatás során felmérésre kerültek a nemzetközi szakirodalom és a szakma szabályai szerinti utazási tanácsadási módszerek és a legfontosabb javaslatok. Továbbá megvizsgáltuk, hogy ezek hogyan adaptálhatóak a megváltozott utazási feltételekhez. Célszerúnek látszott az utazás előtti, a világjárványt is figyelembe vevő utazási kockázatokat is elemezni, hogy azok minél jobban megfeleljenek az utazásorvostani prevenció követelményeinek. A prevenciós módszerek alapjául az utazásorvostan három megelőző módszerét (biomedicinális triászát), a vakcinációt, a gyógyszeres védekezést (például maláriatabletta) és az életmódi tanácsokat vettük. Az egyes megelőzó intézkedéseket az utazás kockázati tényezőinek megfelelő sorrendben tárgyaljuk az utazó-, az utazás- és a célország kockázati tényezóit figyelembe véve.

\section{Eredmények}

Sajnálatos módon eddig - nem csak hazánkban - az utazók túlnyomó többsége elmulasztotta az utazás előtti tanácsadás és vakcináció igénybevételét (LENGYEL-FELKAI 2018, HAMER-CONNOR 2004). Az utazás előtti orvosi tanácsadás első lépése, hogy az orvos felméri az utazó saját kockázatait: az életkort, az esetlegesen meglévó betegségeket és az utazó magatartásbeli attitúdjeit. Fóleg az idósebb nemzedék számára létfontosságú ez, hiszen az ebben a korban már gyakori krónikus betegségek állapotának, gyógyszerelésének kezelóorvos általi felülvizsgálata biztosítja, hogy az utazás alatt nagy valószínúséggel ne következzen be állapotromlás. A COVID által leginkább veszélyeztetett korosztály éppen az idôs korú populáció, akiknél a - sokszor fatális - szövődményekhez a gyakorta meglévő multimorbiditás jelentősen hozzájárul (YANG et al. 2020, KANG-JUNG 2020). Ajánlatos komolyan venni az endémiás ${ }^{2}$ területre utazóknak a javasolt védőoltások felvételét, a malária elleni védekezési formák betartását. Nemcsak az idősek veszélyeztetettek, hanem a gyermekek is, hiszen nekik is törékenyebb a biológiai védekezóképességük, bár az eddigi tapasztalatok alapján a vírusfertőzést könnyebben vészelik át (LUDVIGSSON 2020).

A cseppfertózéssel terjedô vírus a beteg ember légutaiból repül ki köhögés, tüsszentés alkalmával, és nemcsak más, egészséges emberek légutaiba jutva fertôz, hanem sajnálatos módon megmarad a tárgyak felszínén is, így érintéssel is terjedhet. Ezért a gyakori kézmosás csökkenti a fertőző ágensek megtapadását a kezünkön. Nem szükséges azonban fertőtlenító oldatot használni. Tudományos kísérletek bizonyítják, hogy a szappanos kézmosás sok kórokozó esetében hatékonyabb, mint az alkoholbázisú fertôtlenítőszerek (TULADHAR et al. 2015). A rendszeres kézmosás 20-40\%-kal csökkenti a légúti és az emésztőrendszeri fertőzések számát (LUBY et al. 2005). A higiénés szabályok betartása egyértelmúen függ az utazó pozitív attitúdjeitól, ezért a tanácsadás alkalmával fel kell mérni az utazó hozzáállását a szigorító intézkedésekhez, és a tanácsadás taktikáját ehhez kell igazítani.

Az utazás kockázatai közé tartozik az utazáshoz igénybevett jármú. Noha a kontinensen belüli

endémia: meghatározott területen folyamatosan fellelhető járványos betegség 
utazás fő eszköze valószínúleg a gépkocsi, a vonat és a lakóautó lesz, a nemzetközi turizmus - mutatis mutandis - repülógépen fog bonyolódni. A Nemzetközi Légi Szállítási Szövetség (IATA) szakértői szerint a belföldi légi járatok már 2020-ban visszaálltak a régi üzemmódra, míg a nemzetközi járatok teljes újraindulását csak 2022-re prognosztizálják (IATA 2020a), sőt vannak olyan felmérések, melyek csak 2024-re teszik ezt az időpontot (1. ábra).

\section{Az egyik legnagyobb légitársaság veszteglő} repülőgépei a Liszt Ferenc repülőtéren

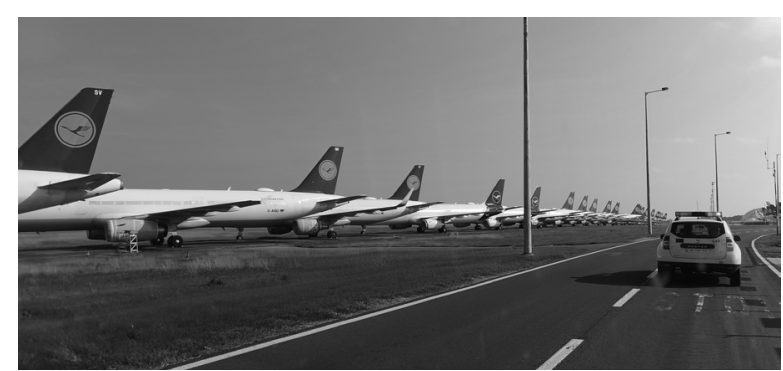

Forrás: a szerző saját felvétele

A biztonságos, COVID utáni repülőgépes utazás előfeltétele az, hogy a repülőtársaságoknak szakítaniuk kell az eddigi üzemanyag takarékosságot célzó megoldásaikkal: az utastérben a takarékos szellőztetés szokásával és a minél több utas egy járatgépre való bezsúfolásával. Az eddigi 50\%-os utastérbéli légcserélés (mely igen üzemanyag takarékos megoldás volt) helyett az utastér teljes levegőjét kellene rendszeresen cserélni. A megfelelő szellőztetés csökkenti a levegóben lévő kórokozók számát és így a fertőzés veszélyét. A külső levegő gyakorlatilag csíramentes, míg a visszakeringtetett levegót úgynevezett HEPA filter (high efficiency particulate air filter - nagyhatású levegő részecske szúrő) szúri meg. A leghatásosabb HEPA filter a 0,1-0,3 $\mu$ m nagyságú részecskéket 99,97\%-os, míg a többit 100\%-os hatásfokkal szúri meg (SCHULTZFUCHTE 2020). Sajnálatos módon a COVID vírusának mérete ennél kisebb, 0,08 $\mu \mathrm{m}$ (GUY et al. 2000).

A légcsere takarékos volta és a fedélzeti fertőzések lehetnek az okai a repülés után gyakran jelentkező felsőlégúti hurutoknak. A védőmaszk viselésére vonatkozó kutatások és előírások sokszor ellentmondóak, mivel azonban cseppfertőzéssel terjedő betegségről van szó, nyilvánvaló, hogy saját védelmünkben érdemes viselni, főleg olyan zsúfolt környezetben, mint a közlekedési eszközök, például a repülőgépek turistaosztálya (JEFFERSON et al. 2008). Éppen a korábbi SARS járvány epidemi- ológiai vizsgálatánál derült ki az, hogy a repülőgépen az egymás körül ülő utasok megfertőzhetik egymást (OLSEN et al. 2003) (2. ábra).

2. ábra

A SARS fertőzés hordozójának helye azon a repülógépen (fekete körrel jelölve), amellyel a világjárványt okozó - 22 másik, távol uulō utastársát is megfertôzô - kínai orvos utazott Hong Kongba

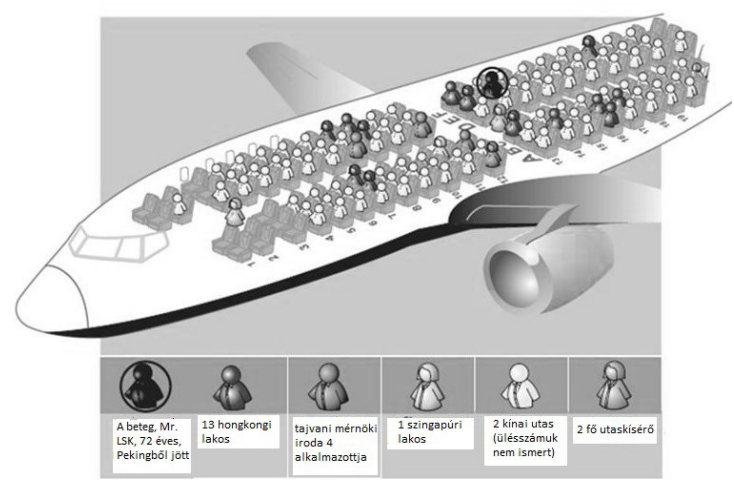

Forrás: OLSEN et al. (2003) nyomán

Így felmerül a kérdés, hogy az utasok milyen távol üljenek egymástól. Az úgynevezett szociális távolság méretére nincsenek pontos vizsgálatok: 1 métertől - 8 méterig terjednek az ajánlások (WHO 2020, BOUROUIBA 2020). Nyilvánvaló azonban, hogy a turistaosztályon utazó, egy sorban lévő 10 ülésben szorongó utasok bármilyen légúti fertőzést átvihetnek az utastársaikra. Az ülések közötti távolság növelése az utazási trombózis megelőzésének szempontjából is ajánlott. Sajátos, hogy a Nemzetközi Légi Szállítási Szövetség elveti a középsô ülés üres távolságtartó megoldását, helyette a levegóben lévő részecskék felkavarását megelőzendô, a limitált utas mozgást részesíti előnyben a kabinon belül (IATA 2020b). A limitált mozgás viszont elősegíti az utazás okozta mélyvénás trombózis kialakulását. Nyilvánvaló, hogy a fedélzeti étkeztetést ezek az intézkedések korlátozzák - az ebból származó megtakarítás fedezheti az ülések szellôsebb vagy új, úgynevezett Janus formációban való elhelyezését (3. ábra).

A nagy rotavírus járványok idején vezették be, hogy a szállodahajók bejáratánál fertőtlenítőszert adagoló palackokat helyeztek el. Ez a megoldás járható út lehet a repülőgép fedélzetére történő belépés előtt is. Javasolt tehát az utazók részére a törlőkendős fertőtlenítő gyakori használata, hiszen a biztonsági ellenőrzésen bizonyosan nem vihetôek át a spray vagy folyékony formájú fertôtlenítő szerek. 
3. ábra Az úgynevezett jin-jang vagy Janus elhelyezés a repülögép kabinjában

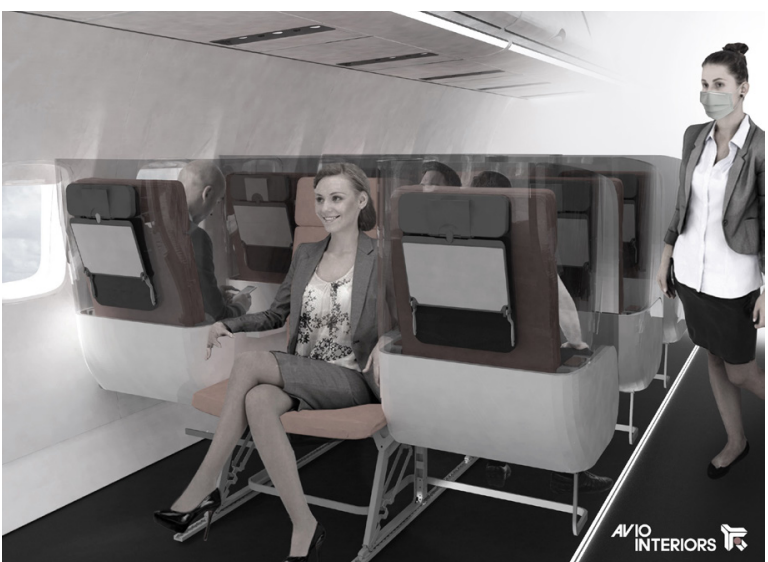

Forrás: a fényképet az Aviointeriors cég (Olaszország) bocsájtotta rendelkezésre

A csomagok saját kezelése a csomagfelvételnél mindenképpen csökkenti a kontaktfertőzés veszélyét. A repülőterek csomagkezeléséhez már kaphatóak ultraibolya fényt előállító fertőtlenítő lámpák, melyek alkalmazása magasabb szintre emelheti a védelmet. Az úti patikában is helyet kell kapjon a szájmaszk, a torokfertőtlenítő folyadék (a COVID vírusa a szájnyálkahártyán keresztül hatol be a szervezetbe) és a fertőtlenítő kendő. A hotelszobákban a fertőtlenítést és a takarítást a járvány lecsengése után nyilvánvalóan fokozott gondossággal végzik majd, de nem árt, ha a fürdőszoba tárgyait és az ágyak környékét (lámpa, kilincs, távirányító, fogas stb.) az utazó maga is újra fertőtleníti.

A szállás kitüntetett pontjainak ismételt fertőtlenítése átvezet a célország kockázati tényezőinek felméréséhez és azok kiküszöböléséhez. Jelen tanulmányban nem soroljuk fel a különféle desztinációk rizikófaktorait, csak a COVID megelőzése szempontjából fontos tényezőket emeljük ki. Sokszor elhanyagolt óvintézkedés külföldön fóleg a trópusi országokban - a biztonságos ételés italfogyasztásra való törekvés. Az utazás alatti megbetegedések felét a romlott vagy szokatlan ételek, illetve a fertőzött ivóvíz okozza. Bár sem a megfelelően kezelt ételekben, sem az ivóvízben nem mutattak ki vírust (CDC 2019), az utcai árusoktól vásárolt ételek, illetve a nem gyárilag csomagolt és palackozott italok veszélyt jelentenek, hiszen a gyomor- és bélrendszeri fertőzésekben legyengült szervezet sokkal fogékonyabb a további fertőzésekre. Ezért - fóleg trópusi országokban - fokozottan érvényes a 4F szabály: az ételt főzd meg, vagy forrald fel, vagy fejtsd le a héját - és ha egyik sem kivitelezhető: felejtsd el (FELKAI 2011).
Mivel az egyes országok eltérô járványvédelmi intézkedéseket léptettek életbe, például az adott országba történó belépésnél bemutatandó PCR teszt eredmények érvényességi idejét illetően (ami 24 órától 7 napig terjedhet). Az utazás előtti tanácsadás során célszerú utánanézni, hogy az utazás célországánál milyen aktuális előírások és korlátozások vannak érvényben. Az utazónak és az utaztatónak tisztában kell lennie az adott ország COVID átfertőződésének mértékével vagy veszélyeztetettségének jellegével, illetve az egyes régiókban megkövetelt intézkedésekkel. Figyelmeztetni kell az utazót arra, hogy a PCR tesztek elvégzésének is van átfutási ideje, ezért a légi utazás időpontját ezt szem előtt tartva kell megtervezni.

A szerző személyes tapasztalata az, hogy a 2020. év közepén újból megnyílt utazási lehetôségekkel párhuzamosan jelentősen megnőtt az utazási biztosítások eladási száma. (Az év második felében az ismét bevezetett utazási korlátozások nyomán megint visszaesett). Az új helyzet új utasbiztosítási termékeket is követelt: a COVID járvánnyal együtt járó káreseményeket az új módozatok is követik. Az utazás előtt tehát ajánlatos ellenőrizni, hogy COVID fertőzés esetén a kezelést, a karantén költségeit, illetve az elhalasztott vagy törölt repülőgépjáratok díját is fedezi-e a biztosítás.

\section{4. Összegzés}

Nyilvánvaló, hogy a végleges megoldást a nyugodt, akadálymentes utazáshoz csak a koronavírus elleni védőoltás bevezetése fogja meghozni. De addig sem szerencsés az utazásokat túlzott mértékben korlátozni vagy a nemzetközi forgalmat nehézkessé tenni. Mindössze néhány elemi egészségügyi és megkerülhetetlen infektológiai tényt kell a cselekvés nyelvére lefordítani, mint például a védőeszközök beszerzését, az ésszerú járványmegelőző intézkedések megtételét és a megfelelő mennyiségú statisztikai adat megszerzését. El kell érni, hogy az egyén bízzon a kormányzati intézkedések szakszerúségében és hatásosságában.

A kormányzat feladatai mellett az utazási ipar szereplóinek is van tennivalója: meg kell találni az egyensúlyt a jövedelmezôség és az elszabadult tömegturizmus ártalmai között, illetve az utóbbiakat a minimálisra szükséges csökkenteni. Az egyének közötti (helytelenül közösségi vagy társadalmi távolságnak nevezett) megfelelő távolságot biztosító megoldások, a fertôtlenítés és a személyi higiéniás lehetőségek biztosítása, valamint az infekciókontroll nem csak egészségügyi intézményekben való alkalmazása a világjárvány utáni szolgáltatói feladatok követelménye. Világosan kell látni azonban, hogy mindezek az intézkedések a szolgáltatások 
nagymérvú drágulását fogják eredményezni. Az olcsó tömegturizmus és a néha már eszement spórolási javaslatok (például állóülések a repülőgépen) csak profitnövelést célzó hatásáról le kell mondani. Mégis, a COVID járvány utáni utazás biztonságát leginkább az utazó magatartása fogja meghatározni. Ezért a jövőbeli utazók felvilágosítása az utazási ipar résztvevőinek egyik fontos feladatát képezi.

\section{Felhasznált irodalom}

BOUROUIBA, L. (2020): Turbulent gas clouds and respiratory pathogen emissions: Potential implications for reducing transmission of COVID-19. JAMA. 323(18). pp. 1837-1838. doi: 10.1001/jama.2020.4756

FELKAI P. - PARAGH GY. (szerk.) (2011): Az utazásorvostan tankönyve. Medicina Könyvkiadó.

FELKAI P. (2018): SARS: a szuperszonikus betegségek korának kezdete - in memoriam Carlo Urbani (1956-2003). Orvosi Hetilap. 159(52). pp. 2226-2229. https://doi.org/10.1556/650.2018.HO2616

GUY, J. S. - BRESLIN, J. J. - BREUHAUS, B. - VIVRETTE, S. - SMITH, L. G. (2000): Characterization of a coronavirus isolated from a diarrheic foal. Journal of Clinical Microbiology. 38(12). pp. 4523-4526.

https://doi.org/10.1128/JCM.38.12.4523-4526.2000

HAMER, D. H. - CONNOR, B.A. (2004): Travel health knowledge, attitudes and practices among United States travelers. Journal of Travel Medicine. 11(1). pp 23-26.

https://doi.org/10.2310/7060.2004.13577

JEFFERSON, T. - FOXLEE, R. - DEL MAR, C. - DOOLEY, L. - FERRONI, E. - HEWAK, B. - PRABHALA, A. - NAIR, S. - RIVETTI, A. (2008): Physical interventions to interrupt or reduce the spread of respiratory viruses: systematic review. BMJ. 336(7635). pp. 77-80. doi: 10.1136/bmj.39393.510347.BE

KANG, S-J. - JUNG, S. I. (2020): Age-related morbidity and mortality among patients with COVID-19. Infect Chemother. 52(2). pp. 154-164. doi: $10.3947 /$ ic.2020.52.2.154

LENGYEL, I. - FELKAI, P. (2018): Pre-travel advice and patient education of Hungarian travellers. Orvosi Hetilap. 159(9). pp. 357-362. doi: $10.1556 / 650.2018 .30987$

LUBY, S. P. - AGBOATWALLA, M. - FEIKIN, D. R. - PAINTER, J. - BILLHIMER, W. -ALTAF, A. - HOEKSTRA, R. M. (2005): Effect of hand washing on child health: a randomized controlled trial. Lancet. 366(9481). pp. 225233.

doi: 10.1016/S0140-6736(05)66912-7
LUDVIGSSON, J. F. (2020): Systematic review of COVID-19 in children shows milder cases and a better prognosis than adults. Acta Paediatrica. 109(6). pp. 1088-1095.

DOI: 10.1111/apa.15270

OLSEN, S. J. - CHANG, H-L. - CHEUNG, T. Y-Y. - TANG, A. F-Y. - FISK, T. L. - OOI, S. P-L. - KUO, H-W. - JIANG, D. D-S. - CHEN, K-T. - LANDO, J. - HSU, K-H. - CHEN, T-J. DOWELL, S. F. (2003): Transmission of severe acute respiratory syndrome on aircraft. The New England Journal of Medicine. 349(25). pp. 2416-2422. doi: 10.1056/NEJMoa031349

SCHULTZ, M. - FUCHTE, J. (2020): Evaluation of aircraft boarding scenarios considering reduced transmissions risks. Sustainability. 12(13): 5329. https://doi.org/10.3390/su12135329

TULADHAR, E. - HAZELEGER, W. C. KOOPMANS, M. - ZWIETERING, M. H. - DUIZER, E. - BEUMER, R. R. (2015): Reducing Viral Contamination From Finger Pads: Handwashing Is More Effective Than Alcohol-Based Hand Disinfectants. The Journal of Hospital Infection. 90(3). pp. 226-234. doi: 10.1016/j.jhin.2015.02.019

YANG, J. - ZHENG, Y. - GOU, X. - PU, K. CHEN, Z. - GUO, Q. - JI, R. - WANG, H. WANG, Y. - ZHOU, Y. (2020): Prevalence of comorbidities in the novel Wuhan coronavirus (COVID-19) infection: a systematic review and meta-analysis. International Journal of Infectious Diseases. 94. pp. 91-95.

https://doi.org/10.1016/j.ijid.2020.03.017

\section{Internetes források}

CDC (CENTERS FOR DISEASE CONTROL AND PREVENTION) (2019): Food and Coronavirus Disease 2019. https://www.cdc. gov/coronavirus/2019-ncov/daily-life-coping/ food-and-COVID-19.html, Letöltve: 2020. június 23.

IATA (INTERNATIONAL AIR TRANSPORT ASSOCIATION) (2020a): IATA Updates COVID-19 Financial Impacts - Relief Measures Needed. https://www.iata.org/en/pressroom/ pr/2020-03-05-01, Letöltve: 2020. június 23.

IATA (INTERNATIONAL AIR TRANSPORT ASSOCIATION) (2020b): IATA Calls for Passenger Face Covering and Crew Masks. Press release: 39. https://www.iata.org/en/pressroom/ pr/2020-05-05-01/, Letöltve: 2020. augusztus 2.

OECD (ORGANISATION FOR ECONOMIC COOPERATION AND DEVELOPMENT) (2020a): Coronavirus pandemic is an unprecedented 